\title{
Solutions to Overseas Protection of China's Geographical Indications
}

\author{
Yuanhua Zhu \\ School of Public Affairs, University of Science and Technology of China, Hefei, China \\ Email: zyh1976@mail.ustc.edu.cn
}

How to cite this paper: Zhu, Y.H. (2018) Solutions to Overseas Protection of China's Geographical Indications. Open Journal of Social Sciences, 6, 146-160.

https://doi.org/10.4236/jss.2018.610012

Received: September 27, 2018

Accepted: October 26, 2018

Published: October 29, 2018

Copyright (C) 2018 by author and Scientific Research Publishing Inc. This work is licensed under the Creative Commons Attribution International License (CC BY 4.0).

http://creativecommons.org/licenses/by/4.0/

\begin{abstract}
Geographical indication is one of the intellectual property rights protected by several multilateral agreements. Among these agreements, Agreement on Trade-related Aspects of Intellectual Property Rights (TRIPS Agreement) has the most members and is most influential as well, but a multilateral system of notification and registration of geographical indications has not been established up to now. In order to give better protection to China's geographical indications in overseas market, additional measures must be taken. Firstly, China's geographical indications can be registered in target countries. Secondly, the Chinese government should sign bilateral agreements on geographical indications protection with other countries. Thirdly, China has been taking part in several negotiations on free trade area, and the protection of geographical indications should also be taken into consideration. Lastly, the Madrid system of international registration for trademarks is also a practical way.
\end{abstract}

\section{Keywords}

Geographical Indication, Overseas Protection, Bilateral Agreements, Madrid System

\section{Introduction}

Agreement on Trade-related Aspects of Intellectual Property Rights defined geographical indications (GIs) as "indications which identify a good as originating in the territory of a Member, or a region or locality in that territory, where a given quality, reputation or other characteristic of the good is essentially attributable to its geographical origin". In chronological order, there are four major multilateral treaties related to the protection of geographical indications: Paris Convention on the Protection of Industrial Property, Madrid Agreement for the 
Repression of False or Deceptive Indications of Source on Goods, Lisbon Agreement for the Protection of Appellations of Origin and Their International Registration and Agreement on Trade-related Aspects of Intellectual Property Rights. China is the member of the first one and fourth one.

The Paris Convention is the first multilateral treaty to protect geographical indications, but it only makes a simple provision in article 9 and article 10, doesn't offer feasible legal remedies for the right owners, as well as lacks supervisory mechanism, has no sanction measures if certain members violate their obligation.

The TRIPS Agreement, which has 164 members so far, is the most influential agreement on the protection of geographical indications. Relying on the dispute settlement mechanism of the World Trade Organization, it can be said that it establishes the first global geographical indications protection system [1]. However, the TRIPS Agreement only sets the minimum standards for the protection of geographical indications, and its members are not obliged to grant automatic protection to foreign geographical indications. The fundamental reason is that the Agreement has not established the multilateral system of notification and registration of geographical indications. Therefore, additional solutions are needed to ensure that China's geographical indications are better protected in other countries.

Geographical indications are mainly used on agricultural products, especially on those of high quality. With the development of world economy, the demands for qualified agricultural products will be more and more. The overseas protection of China's geographical indications is of great significance in expanding the exportation of Chinese agricultural products, defending the interests of Chinese farmers and other relevant operators. Moreover, it is very important in enhancing the image of Chinese agricultural products in international markets.

\section{Solutions to Overseas Protection of China's Geographical Indications}

\subsection{Applying for Registration in Target Market Countries}

To protect Chinese geographical indications in other countries, the most direct way is to seek protection from the department in charge according to the geographical indication management system of the target market countries. Different countries and regions have different models for the protection of geographical indications. The WTO secretariat has once conducted a questionnaire survey on member states. According to the responses of 43 members and the European Union, the legal protection of their geographical indications can be divided into three types: laws focusing on business practices, trademark law, and special protection [2].

For the registration of geographical indications in the target market country, it is necessary to study the relevant legal system of the country and register it according to the requirements and procedures issued by the country. In the United 
States, for example, geographical indications are protected mainly by trademark law: the Lanham Act. Chinese applicants may apply to the United States Patent and Trademark Office (USPTO) for the registration of geographical indications. When filing an application for trademark registration to the USPTO, you must specify the application bases, such as "use in commerce" and "intend-to-use" [3]. Since trademark law in the United States emphasizes the use of trademarks, it is necessary to provide a lot of evidences of their use in applying for a registered trademark. If Chinese geographical indications are to be registered as trademarks in the United States, the applicants must pay attention to the collection of evidence, such as contracts, advertisements, publicity materials and so on [4].

The advantage of applying for protection in target market countries is that it is direct and effective. However, it is very time-consuming to register single or multiple geographic indications in many countries or regions. In addition, it is difficult for the applicants who are not familiar with the legal environment of other countries. Therefore, this method is more suitable for geographical indications with the following characteristics: the sales area of the products of geographical indications are relatively concentrated, the operators have rich international trade experience and are abundant in financial expenses.

\subsection{Protection through Bilateral Agreements}

To sign bilateral agreements on the protection of geographical indications is a traditional means which plays an active and important role in the protection of geographical indications. In this aspect, the European Commission is the most active practitioner. Through bilateral agreements, the EC supplements the provisions of the TRIPS Agreement and protects its specific geographical indications such as wine and spirits (Table 1).

Bilateral agreements can be divided into two types: one is a specialized agreement and the other is a comprehensive agreement. The former refers to the agreement specifically or mainly signed to solve the problem of geographical indications protection, while the latter refers to the content of the agreement including, but not limited to, the protection of geographical indications. In the case that the TRIPS agreement fails to reach a consensus on multilateral system of notification and registration of geographical indications, to sign bilateral agreements is an inevitable choice.

\subsubsection{The Project of Mutual Recognition and Protection of Geographical Indications between China and the European Union}

As to geographical indication protection, there is a common ground between China and EU. First, both China and the EU are among the world's top economies, they trade closely and each one is an important trading partner of the other. Statistics shows that China is the EU's largest import trading partner in 2017. The EU imports from China accounted for 20 percent of its total imports from outside the region. China is also the second largest market of the EU's export, 
Table 1. Some of the bilateral agreements the EC signed for GIs protection.

\begin{tabular}{|c|c|c|}
\hline State & Year & Agreement name \\
\hline Australia & 1994 & $\begin{array}{l}\text { Agreement between the European Community and Australia on } \\
\text { trade in wine }\end{array}$ \\
\hline $\begin{array}{l}\text { the United Mexican } \\
\text { States }\end{array}$ & 1997 & $\begin{array}{l}\text { Agreement between the European Community and the United } \\
\text { Mexican States on the mutual recognition and protection of } \\
\text { designations for spirit drinks }\end{array}$ \\
\hline the Republic of Chile & 2002 & $\begin{array}{l}\text { Agreement establishing an association between the European } \\
\text { Community and its Member States, of the one part, and the Republic } \\
\text { of Chile, of the other part }\end{array}$ \\
\hline $\begin{array}{l}\text { the Republic of South } \\
\text { Africa }\end{array}$ & 2002 & $\begin{array}{l}\text { Agreement between the European Community and the Republic of } \\
\text { South Africa on trade in wine }\end{array}$ \\
\hline Canada & 2004 & $\begin{array}{l}\text { Agreement between the European Community and Canada on trade } \\
\text { in wines and spirit drinks }\end{array}$ \\
\hline $\begin{array}{l}\text { the United States of } \\
\text { America }\end{array}$ & 2006 & $\begin{array}{l}\text { Agreement between the European Community and the United States } \\
\text { of America on trade in wine-Declarations }\end{array}$ \\
\hline $\begin{array}{c}\text { the Republic of } \\
\text { Moldova }\end{array}$ & 2014 & $\begin{array}{l}\text { Agreement between the European Community and the Republic of } \\
\text { Moldova on reciprocal preferential trade concessions for certain } \\
\text { wines }\end{array}$ \\
\hline
\end{tabular}

accounting for 11.1 percent of the EU's total exports outside the region [5]. Both China and the EU have a long history and splendid culture, both are rich in geographical indication resources and attach importance to the protection of geographical indications. Moreover, the products of geographical indications of China and the EC are complementary to each other to a certain extent. For example, the EU's wines sell well in China, while Chinese tea and ceramics have been popular in Europe since ancient times. In view of this, China-EU cooperation in geographical indications can achieve a win-win effect. There are three landmark events in the China-EU project of mutual recognition and mutual protection of geographical indications.

One event is the "ten plus ten" project between China and the EU. On September 5, 2005, a Memorandum of Understanding on Geographical Indications was signed between the General Administration of Quality Supervision, Inspection and Quarantine of the PRC and the Department of Trade of the EU. Based on the Memo, China and the EU will list10geographical indications respectively, and give mutual recognition and protection to the other side. This project was formally started in 2007. By November, 2012, through the joint efforts of government agencies, experts and manufacturers of geographical indication products from China and the EU, twenty geographical indications (Table 2) has been approved and protected, which marks the successful completion of the project. This is the first time that the EU accepted the application for protection of 10 geographical indications from other country, which marks a historic breakthrough in international cooperation on geographical indications.

The other event is the "a hundred plus a hundred" project. Based on the "ten plus ten" project mentioned above, China and the EU started the " $100+100$ " 
Table 2. List of the GIs protected in China-the EU "ten plus ten" project.

\begin{tabular}{|c|c|c|c|}
\hline \multirow{2}{*}{ Number } & \multicolumn{2}{|c|}{ China's GIs protected in the EU } & \multirow{2}{*}{$\begin{array}{l}\text { the EU's GIs protected } \\
\text { in China }\end{array}$} \\
\hline & Chinese name & Transcription & \\
\hline 1 & 龙口粉丝 & Longkou Fen $\mathrm{Si}$ & $\begin{array}{c}\text { Pruneaux d'Agen/Pruneaux } \\
\text { d'Agen mi-cuits }\end{array}$ \\
\hline 2 & 龙井茶 & Longjing Cha & Roquefort \\
\hline 3 & 琯溪蜜柚 & Guanxi Mi You & Comté \\
\hline 4 & 䖧县麻山药 & Lixian Ma Shan Yao & $\begin{array}{l}\text { West Country Farmhouse } \\
\text { Cheddar }\end{array}$ \\
\hline 5 & 陕西苹果 & Shaanxi ping guo & Scottish Farmed Salmon \\
\hline 6 & 金乡大蒜 & Jinxiang Da Suan & Sierra Mágina \\
\hline 7 & 镇江香醋 & Zhenjiang Xiang Cu & Priego de Cordóba \\
\hline 8 & 盐城龙虾 & Yancheng Long Xia & Grana Padano \\
\hline 9 & 平谷大桃 & Pinggu Da Tao & $\begin{array}{l}\text { White Stilton Cheese/Blue Stilton } \\
\text { Cheese }\end{array}$ \\
\hline 10 & 东山白芦笋 & Dongshan Bai Lu Sun & Prosciutto di Parma \\
\hline
\end{tabular}

Source: The General Administration of Quality Supervision, Inspection and Quarantine of the PRC.

project since 2011. According to the project, each side has submitted 100 geographical indications respectively based on the product popularity, economic benefits, quality and technical requirements. The implementation of "a hundred plus a hundred" project marks the "ten plus ten" project has been recognized by both China and the EU. A list of the 200 geographical indications between China and Europe (Appendix 1) was published on the official website of the European commission on June 2, 2017.

The third event is the negotiations of Agreement between China and the EU on cooperation of Geographical Indications which has been started from March, 2011. Sixteen rounds of negotiations have been held so far, which shows how arduous the negotiations are. On July 16, 2018, Li Keqiang, Premier of the State Council of the People's Republic of China, and Donald Tusk, President of the European Council, and Jean-Claude Juncker, President of the European Commission, held the twentieth China-EU leaders' meeting in Beijing and issued $A$ Joint Statement on the Twentieth China-EU Leaders' Meeting. The joint statement shows that the two sides agreed to speed up the negotiations on the agreement and committed to make substantial progress in the next round of negotiation. The negotiation will be ended y the end of October, 2018 if possible.

The Agreement between China and the EU on cooperation of Geographical Indications will be the first agreement between the governments of China and the EU on the protection of geographical indications. After signing the agreement, China's products of geographical indication will enter the EU market more conveniently. It has great influence on expanding the export of Chinese agricultural products, and expanding the popularity of Chinese agricultural products brands in international market, and promoting the development of ru- 
ral economy of China.

The agreement will be of great significance in the protection of geographical indications in China. This shows that China's protection system of geographical indication product conforms to internationally recognized standards, and its examination procedures and technical requirements can fully link up with countries and regions with developed geographical indications protection systems, such as the European Union. It will play an important role in perfecting the construction of the special protection system of geographical indications in China, improving the level of intellectual property protection, and enhancing the international image of China's intellectual property protection.

The project explores an effective way for the overseas protection of geographical indications in China. The basic path of the project is: to launch a pilot project at first, in this step, several geographical indications are listed, then to expand the list, and finally to sign a formal agreement. This practice can be extended to the cooperation with other countries and regions.

\subsubsection{Bilateral Agreement on Free Trade Area}

China has also actively explored the use of bilateral agreements to protect geographical indications. Since 2003, the Chinese government has vigorously promoted the construction of free trade zones, and has signed 16 agreements ${ }^{1}$ with Switzerland, South Korea and other countries, involving 24 countries or regions.

Among the agreements that have been signed, four are related to geographical indications (Table 3), special articles are provided. Another one which is worth mentioning is the Agreement with New Zealand. In the definition of "intellectual property" in chapter 12, article 159, the agreement provided that "geographical indication" is one of the intellectual property rights defined in the TRIPS Agreement, but there are no more detailed contents, nor is there a list of mutually recognized geographical indications like in the other three.

Through the agreement of free trade area to protect the geographical indication, China has accumulated some experience and achieved preliminary results. However, some problems have also emerged. First, the number of agreements relating to geographical indications protection is small, accounting for merely $25 \%$ of the total. Second, the number of geographical indications on the list of relevant agreements is small, too. The third is that the level of protection on these geographical indications is not high enough, only basic protection consistent with the TRIPS Agreement are provided. Finally, the names of the listed geographical indications are not uniform in language and characters, some in Chinese characters, some in Latin letters, while others in both Chinese characters and Latin letters.

${ }^{1}$ The 16 agreements include 13 agreements China signed with the following countries or association: Maldives, Georgia, Australia, Korea, Switzerland, Iceland, Costa Rica, Peru, Singapore, New Zealand, Chile, Pakistan, the Association of Southeast Asian Nations. The other three ones are: The Cross-Strait Economic Cooperation Framework Agreement, the Mainland and Hong Kong Closer Economic Partnership Arrangement, as well as the Mainland and Macau Closer Economic Partnership Arrangement. (Source: official website of General Administration of Customs of China) 
Table 3. Bilateral agreements concerned GIs China signed in FTA.

\begin{tabular}{cclc}
\hline State & Year & \multicolumn{1}{c}{ Main contents } & Number of GIs \\
\hline Chile & 2005 & $\begin{array}{l}\text { Mutually recognize the listed GIs, protect them } \\
\text { according to the TRIPS Agreement. } \\
\text { Mutually recognize the listed GIs, protect them } \\
\text { according to the TRIPS Agreement. } \\
\text { The protection can be expanded to other GIs } \\
\text { after negotiation. }\end{array}$ & $\begin{array}{c}\text { China:2 } \\
\text { Chile:1 }\end{array}$ \\
Costa Rica & 2009 & $\begin{array}{l}\text { Mutually recognize the listed GIs, protect them } \\
\text { according to the TRIPS Agreement. }\end{array}$ & $\begin{array}{c}\text { Phina: to be listed } \\
\text { Costa Rica:10 }\end{array}$ \\
\hline
\end{tabular}

Source: Website of China Free Trade Area Network.

At present, agreements between China and Norway, Sri Lanka, Israel and other countries are under negotiations, agreements with Singapore, New Zealand, and other countries are in the process of being upgraded, free trade zones with Canada, Bangladesh and other countries have also been in study, the above problems are expected to be solved in the future.

\subsubsection{Bilateral Agreements under the "Belt and Road" Initiative}

The "Belt and Road" initiative refers to the cooperative initiative proposed by China's President Xi Jinping in 2013to build the "Silk Road Economic Belt" and the "21st Century Maritime Silk Road". The initiative aims to build a community of shared interests, shared future and shared responsibility for political mutual trust, economic integration and cultural inclusion by developing economic partnership with countries along the belt and road through the existing bilateral and multilateral mechanisms and regional cooperation platforms. Since the "Belt and Road" initiative was proposed, it has received high attention from the international community, and relevant countries have actively participated in it. In the speech at the opening ceremony of the Boao Forum for Asia 2018 annual conference on April 10, 2018, Xi Jinping said that more than 80 countries and international organizations have signed cooperation agreement with China over the past five years.

Intellectual property is an important issue in the construction of "Belt and Road" construction. In July, 2016, a high-level conference on intellectual property rights was held in Beijing, during which a round table conference on intellectual property rights was held. An agreement was reached on the "Joint Initiative on Strengthening Cooperation in the Field of Intellectual Property Rights of Belt and Road Initiative". On May 14, 2017, during the Summit Forum on International Cooperation of "Belt and Road", The National Intellectual Property Administration of the PRC and the World Intellectual Property Organization signed the Agreement Between the Government of the People's Republic of China and the World Intellectual Property Organization on Strengthening Cooperation on Intellectual Property Rights of "Belt and Road" in Beijing. This is the first document on cooperation in intellectual property rights relating to "Belt and Road" signed by the Chinese government and international organizations. It 
marks that the two sides will carry out comprehensive and in-depth cooperation around the construction of "Belt and Road", and promote the development of intellectual property rights in countries and regions along belt and road.

The construction of "Belt and Road" international cooperation platform has brought opportunities for the overseas protection of China's geographical indications. While establishing the system of integration of intellectual property rights in the "Belt and Road" region, it is necessary to consider the national situation of different countries concerned and the individual requirements in the protection of intellectual property rights. China has signed bilateral treaties or memorandums with various countries, which can satisfy the interests of both sides, achieve the goal of cooperation [6]. With the further development of the Silk Road Economic Belt, the freight express from China to central Asia and Europe will be more unimpeded than moow, which will save a lot of time and cost for the export of China's goods, more and more products of geographical indications will go abroad.

\subsection{Protection of Geographical Indications in Regional Agreements}

WTO has been playing an important role in promoting the globalization of world economy since its establishment. However, with such a huge trade framework, it is difficult to coordinate the interests of all parties, regional trade agreements therefore have come into being. By 2017, 647 Regional Trade Agreements have been notified to the WTO, of which 433 have entered into force [7]. Some of the Agreements were designed to protect geographical indications, for example, the North American Free Trade Agreement, the Bangui Agreements, and Resolution 486 on the Common System of Intellectual Property of the Andean Community and so on.

There are at least two advantages in protecting geographical indications through regional agreements. The first one is cultural proximity. The difference of dietary culture, for instance, between countries in the same region is smaller than that of the countries far away from each other. For example, Chinese consume more green tea than black tea, while Britons prefer black tea. European and American consumers like cheese, but Chinese consumers are in less demand. The second advantage is that the geographical proximity is convenient for transportation. Products of geographical indications are mostly agricultural products, and a considerable proportion of that are fresh products, the timeliness of delivery is essential, transportation between regional countries have remarkable advantages in this aspect.

At present, China is actively conducting negotiations on regional agreements, such as the Free Trade Agreement Between China, Japan and South Korea, and the Regional Comprehensive Economic Partnership Agreement. Taking the second one as an example, the consultation on this agreement were launched in 2012, with the first round of formal talks held in March, 2013 in Seoul, South Korea, 13 rounds of negotiations have been held so far. If the agreement were 
reached, this free trade area will become the world's third largest economic trade area after the North American Free Trade Area and the European Union. In the negotiation of geographical indication related clauses, if the geographical indications list is involved, it is suggested that each side should carefully choose the products. The complementary products which mean there are no competing products in other sides are preferred. Moreover, if a geographical indication of one side has become a generic name in other sides, it is better not to be listed [8].

\subsection{Protection of Trademarks by International Registration System of Madrid}

Before the establishment of a multilateral system of notification and registration of geographical indications under the TRIPS Agreement, the Madrid system for international registration of trademarks is an effective way to protect geographical indications in overseas market.

The Madrid system is a system for the international registration of trademarks administered by WIPO. The system is governed by two international treaties: one is Madrid Agreement Concerning the International Registration of Marks (hereinafter referred to as "the Madrid Agreement") which was concluded in Madrid in 1891, and the other is Protocol Relating to the Madrid Agreement Concerning the International Registration of Marks (hereinafter referred to as "the Madrid Protocol"), concluded in Madrid in 1989. There are 55 parties to the Madrid Agreement and 101 parties to the Madrid Protocol. The system makes it possible to protect a mark in a large number of countries by obtaining an international registration that has effect in each of the designated contracting parties. China became one of the contracting parties to the Madrid Agreement on October 4, 1989, and that to the Madrid Protocol on December 1, 1995.

At present, the consciousness of Chinese enterprises to register their trademarks through the Madrid system is not strong enough (Table 4), which leads to many Chinese trademarks have been rush registered in other countries. According to incomplete statistics, nearly $15 \%$ of Chinese well-known trademarks have been rush registered abroad and more than 100 cases of trademark infringement

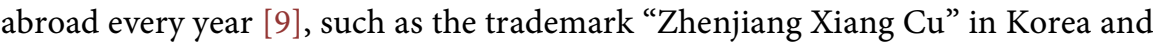
the trademark "WANGZHIHE" in Germany. Although some Chinese companies finally get back the trademark rights through international litigation, a high cost was paid. For example, Beijing Wangzhihe Food Group is a Chinese corporation that specializes in the production and sales of sufu, it applied for the registration of trademark "WANGZHIHE" to the German Patent and Trademark Office in July, 2006, but was noticed that this trademark had already been registered by German OKAI Company. After negotiation but reached no agreement, Wangzhihe Group sued OKAI Company and eventually won the lawsuit in Apr, 2009 [10]. Besides the expenses Wangzhihe Group paid for this lawsuit, the cost of time which is nearly 3 years is also very high.

Some enterprises are forced to change their infringed trademarks to avoid the 
Table 4. Madrid application of China's trademarks (2008-2017).

\begin{tabular}{cccc}
\hline Year & $\begin{array}{c}\text { Total application } \\
\text { (thousand) }\end{array}$ & $\begin{array}{c}\text { Madrid application } \\
\text { (thousand) }\end{array}$ & Percentage \\
\hline 2008 & 698.0 & 0.2059 & $0.29 \%$ \\
2009 & 830.5 & 0.1268 & $0.15 \%$ \\
2010 & 1072.0 & 0.182 & $0.17 \%$ \\
2011 & 1416.8 & 0.2053 & $0.14 \%$ \\
2012 & 1648.3 & 0.21 & $0.13 \%$ \\
2013 & 1881.5 & 0.2273 & $0.12 \%$ \\
2014 & 2275.4 & 0.214 & $0.09 \%$ \\
2015 & 2876.0 & 0.2321 & $0.08 \%$ \\
2016 & 3691.0 & 0.3104 & $0.08 \%$ \\
2017 & 5748.0 & 0.481 & $0.08 \%$ \\
\hline
\end{tabular}

Source: Annual Development Report (2008-2017) of China’s Trademark Strategy issued by State Administration for Industry \& Commerce of the People's Republic of China.

high cost of money and time for redundant lawsuit procedures, this resulted in a huge loss of intangible assets. "LEGEND", for example, once a famous trademark for computer, was substituted by "LENOVO" because it was registered in many countries [11]. The Madrid System is a convenient and cost-effective solution for registering and managing trademarks worldwide. The cost of registering a trademark is obviously more economical than the cost of safeguarding the rights of the trademark after being infringed [10]. It can be said that registration is the best protection.

To register a geographical indication through the Madrid system, the applicants should register it as trademark in China firstly, then apply to the International Registration Division of the Trademark Office of China for international registration. After the formality examination, the International Registration Division applies to the International Bureau of WIPO for registration. If there are no irregularities in the application, the International Bureau of WIPO records the trademark in the International Register, and publishes the international registration in the official publication of the Madrid system, WIPO Gazette of International Marks, and notifies it to each designated Contracting Party.

To protect geographical indications through the Madrid system has many advantages. The first one is linguistic simplicity. The applicant may apply in English or French to the WIPO International Bureau through the trademark office of the home country, without having to apply separately to multiple countries in accordance with the laws relating to the protection of their geographical indications in multiple languages. Second is the economy of expenses. There is no need to pay several different fees to multiple countries, but a set of fees to the WIPO International Bureau. Third is the convenience of management. International registration through the Madrid system is valid for 10 years and may be renewed for a further period of 10 years after payment of the prescribed fee. The Madrid 
system has similar benefits to trademark maintenance and renewal. Likewise, if there is a change in name and/or address, it may be recorded with effect for all designated Contracting Parties by means of a single procedural step.

\section{Conclusions and Future Research}

\subsection{Conclusions}

All protection systems are the reflection of economic interests. The protection of geographical indications is more of an issue of economy than an issue of intellectual property or of consumer protection [12]. China has abundant resources of geographical indications which may become the strengths of China's intellectual property rights [13]. To improve the protection level of China's geographical indications in foreign countries and to protect China's economic interests, the following aspects are suggested.

Firstly, as a member of the TRIPS Agreement, China has the obligations to fulfilling the requirements of the agreement. On the other hand, China has the right to pursue the reasonable interests. China should take a more active part in the formulation of international protection rules. In the negotiations of article 23.4 of the TRIPS Agreement, China should insist on extending the multilateral system of notification and registration for wine and spirits to other geographical indications.

Secondly, National Intellectual Property Administration who is responsible for the management of geographical indications in China should strengthen the propaganda of the international registration of geographical indications, enhance the awareness of international protection of the operators, support and encourage them to carry out international registration.

Thirdly, strengthen the investigation into overseas infringement on China's geographical indications. In this regard, we can study the experience of India by setting up a specialized foundation and contract the task of infringement surveillance around the world to international agencies [14]. Once the infringement such as rush registration occurs, the right owner should immediately file opposition according to the laws of the host country. As to abuse and other infringements, the right owners should file a lawsuit or through consultation and use other ways to protect their legitimate rights and interests.

Finally, we should sum up the experience of the project of "mutual recognition and protection of geographical indications between China and the EU", actively launch bilateral or multilateral negotiations with other countries, sign special agreements on protection of geographical indications and carry out win-win cooperation.

\subsection{Future Research}

This article brings forward several solutions to protect China's geographical indications in overseas markets, but the solutions are generally from a macroscopic perspective, more detailed measures are needed to study in the future. In ad- 
dition, none of the above solutions is universal, China's geographical indications should be divided into different categories according to certain variables, and a certain solution is applied to a certain category to get more effective protection.

\section{Conflicts of Interest}

The author declares no conflicts of interest regarding the publication of this paper.

\section{References}

[1] Gervais, D.J. (1998) The TRIPS Agreement: Drafting History and Analysis. Sweet \& Maxwell, London.

[2] World Trade Organization (1999) IP/C/W/253/Rev.1. https://www.wto.org/english/tratop_e/trips_e/ta_docs_e/5_3_ipcw253rev1_e.pdf

[3] Mei, Y. (2016) How to Obtain and Maintain Trademark Registration in the United States of America. China Trademark, 6, 67-71.

[4] Zhang, Y. (2017) Countermeasures for Overseas Protection of China's Trademark. China Trademark, 6, 18-22.

[5] Ministry of Commerce of the People's Republic of China (2018) China Is the Largest Importer of the European Union. http://www.mofcom.gov.cn/article/i/jyjl/m/201805/20180502747329.shtml

[6] Dai, S.P. and Li, J.B. (2018) Strategies for Intellectual Property Protection in the Construction of "Belt and Road". Journal of Shenyang Normal University (Social Science Edition), 42, 93-97.

[7] Yang, J. and Wang, Z.K. (2017) Viewing the Erosion of Bilateral FTA to Multilateral Trade Rules of WTO from the Perspective of International Law and China's Countermeasures. ChutianFazhi, 9, 214-215.

[8] Na, L. and Wei, D.C. (2013) Comment on Geographical Indications in FTA and China's Choice. Jianghuai Tribune, 4, 120-125.

[9] Wu, X.A. (2017) Warning Mechanism Should Be Established for Preventing Rush Registration of China's Trademark in Overseas Market. China Business Herald, 01.

[10] Li, R.F. and Lv, F. (2014) The Enlightenment of Overseas Rights Protection of Trademark "WANGZHIHE”. Knowledge Economy, 3, 103-104.

[11] Lu, L. (2014) Study on Overseas Rush Registration of Trademark and the Remedies. Lanzhou Academic Journal, 1, 187-191.

[12] Chen, J. (1996) Sober Second Look at Appellations of Origin: How the United States Will Crash France's Wine and Cheese Part. Minnesota Journal of Global Trade, 5, 29-64.

[13] Zheng, C.S. (2002) From "Entry into WTO" and the Protection of Intellectual Property Rights to the Modernization of Civil and Commercial Law. The Annual Symposium of WTO Law Research Society of China Law Society, Beijing.

[14] Wang, X.B. (2004) The Protection of Geographical Indications in India. China Trademark, 4, 42-44. 


\section{Appendix 1}

List of the GIs protected in China-the EU “a hundred plus a hundred" project

\begin{tabular}{|c|c|c|c|}
\hline \multirow{2}{*}{ Number } & \multicolumn{2}{|c|}{ China's GIs protected in the EU } & \multirow{2}{*}{ the EU's GIs protected in China } \\
\hline & Chinese name & Transcription & \\
\hline 1 & 安吉白茶 & Anji Bai Cha & $\mathrm{Zı} \beta \alpha v i \alpha / T \zeta_{\imath} \beta a v i \alpha / Z ı \beta a ́ v \alpha / Z i v a n i a$ \\
\hline 2 & 安溪铁观音 & Anxi Tie Guan Yin & Českobudějovické pivo \\
\hline 3 & 保山小粒咖啡 & Baoshan Xiao Li Ka Fei & Žateckýchmel \\
\hline 4 & 赣南脐橙 & Gannan Qi Cheng & Rheinhessen \\
\hline 5 & 霍山黄芽 & Huoshan Huang Ya & Mosel \\
\hline 6 & 郫县豆瓣 & Pixian Dou Ban & Franken \\
\hline 7 & 普洱茶 & Pu'er Cha & Münchener Bier \\
\hline 8 & 山西老陈醋 & Shanxi Lao Chen $\mathrm{Cu}$ & Bayerisches Bier \\
\hline 9 & 烟台苹果 & Yantai Ping Guo & Danablu \\
\hline 10 & 坦洋工夫 & Tanyang Gong Fu & Irish cream 1 \\
\hline 11 & 白城绿豆 & BaichengLü Dou & $\begin{array}{c}\text { Irish whiskey/Irish } \\
\text { whisky/UisceBeatha Eireannach2 }\end{array}$ \\
\hline 12 & 肇源大米 & Zhaoyuan Da Mi & Oú̧o/Ouzo3 \\
\hline 13 & 娽源绿茶 & WuyuanLü Cha & $\sum \dot{\alpha} \mu \mathrm{oc}$ (Samos) \\
\hline 14 & 福州茉莉花茶 & Fuzhou Mo Li Hua Cha & $\begin{array}{c}\Sigma \eta \tau \varepsilon i a \\
\Lambda \alpha \sigma \iota \operatorname{ciouK\rho \eta ́} \tau \varsigma / \text { SitiaLasithiouKritis }\end{array}$ \\
\hline 15 & 房县香菇 & Fangxian Xiang Gu & 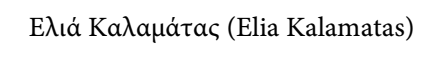 \\
\hline 16 & 南丰蜜桔 & Nanfeng Mi Ju & Maбтíxa Xíov (MastichaChiou) \\
\hline 17 & 苍山大蒜 & Cangshan Da Suan & $\Phi \dot{\tau} \tau \alpha$ (Feta) \\
\hline 18 & 房县黑木耳 & FangxianHei Mu Er & Rioja \\
\hline 19 & 凤冈锌硒茶 & Fenggang Xin Xi Cha & Cava \\
\hline 20 & 库尔勒香梨 & Kuerle Xiang Li & Cataluña \\
\hline 21 & 邳州大蒜 & Pizhou Da Suan & La Mancha \\
\hline 22 & 安岳柠檬 & Anyue Ning Meng & Valdepeñas \\
\hline 23 & 正山小种 & Zhengshan Xiao Zhong & Brandy de Jerez \\
\hline 24 & 兴化香䓤 & Xinghua Xiang Cong & Queso Manchego \\
\hline 25 & 祁门红茶 & Qimen Hong Cha & $\begin{array}{c}\text { Jerez-Xérès-Sherry or Jerez or Xérès } \\
\text { or Sherry }\end{array}$ \\
\hline 26 & 宜宾芽菜 & YibinYa Cai & Navarra \\
\hline 27 & 静宁苹果 & Jingning Ping Guo & Valencia \\
\hline 28 & 安丘大姜 & Anqiu Da Jiang & Sierra Mágina \\
\hline 29 & 建宁通心白莲 & Jianning Tong Xin Bai Lian & Priego de Córdoba \\
\hline 30 & 松溪绿茶 & SongxiLü Cha & Alsace \\
\hline 31 & 罗平小黄姜 & Luoping Xiao Huang Jiang & Armagnac \\
\hline 32 & 苍溪红心猕猴桃 & $\begin{array}{l}\text { Cangxi Hong Xin Mi Hou } \\
\text { Tao }\end{array}$ & Beaujolais \\
\hline
\end{tabular}




\section{Continued}

\begin{tabular}{|c|c|c|c|}
\hline 33 & 庆元香菇 & Qingyuan Xiang Gu & Bordeaux \\
\hline 34 & 长寿沙田柚 & Changshou Sha Tian You & Bourgogne \\
\hline 35 & 凤凰单丛 & Fenghuang Dan Cong & Calvados \\
\hline 36 & 涪城麦冬 & Fucheng Mai Dong & Chablis \\
\hline 37 & 狗牯脑 & Gou Gu Nao & Champagne \\
\hline 38 & 武夷山大红袍 & Wuyishan Da Hong Pao & Châteauneuf-du-Pape \\
\hline 39 & 晋州鸭梨 & Jinzhou Ya Li & $\begin{array}{c}\text { Cognac/eau-de-vie de } \\
\text { cognac/eau-de-vie des charentes }\end{array}$ \\
\hline 40 & 吐鲁番葡萄干 & Turpan Pu Tao Gan & Comté \\
\hline 41 & 安化黑茶 & AnhuaHei Cha & Côtes de Provence \\
\hline 42 & 嵊泗贻贝 & Shengsi Yi Bei & Côtes du Rhône \\
\hline 43 & 辽中玫瑰 & Liaozhong Mei Gui & Côtes du Roussillon \\
\hline 44 & 横县茉莉花茶 & Hengxian Mo Li Hua Cha & Graves \\
\hline 45 & 蒲江雀舌 & Pujiang Que She & Languedoc \\
\hline 46 & 峨眉山茶 & Emeishan Cha & Margaux \\
\hline 47 & 朵贝茶 & Duobei Cha & Médoc \\
\hline 48 & 五常大米 & Wuchang Da Mi & Pauillac \\
\hline 49 & 福鼎白茶 & Fuding Bai Cha & Pays d'Oc \\
\hline 50 & 吴川月饼 & Wuchuan Yue Bing & Pessac-Léognan \\
\hline 51 & 兴隆咖啡 & Xinglong Ka Fei & Pomerol \\
\hline 52 & 绍兴酒 & Shaoxing Jiu & $\begin{array}{l}\text { Pruneauxd "Agen-Pruneauxd" Agen } \\
\text { mi-cuits }\end{array}$ \\
\hline 53 & $\begin{array}{l}\text { 贺兰山东麓 } \\
\text { 葡萄酒 }\end{array}$ & $\begin{array}{l}\text { Helanshan Dong Lu } \\
\text { Pu Tao Jiu }\end{array}$ & Roquefort \\
\hline 54 & 桓仁冰酒 & Huanren Bing Jiu & Saint-Emilion \\
\hline 55 & 烟台葡萄酒 & Yantai Pu Tao Jiu & Tokaj \\
\hline 56 & 惠水黑糯米酒 & HuishuiHeiNuo Mi Jiu & Acetobalsamico di Modena \\
\hline 57 & 西峡香菇 & Xixia Xiang Gu & Asiago \\
\hline 58 & 红崖子花生 & Hongyazi Hua Sheng & Asti \\
\hline 59 & 武夷岩茶 & Wuyi Yan Cha & Barbaresco \\
\hline 60 & 英德红茶 & Yingde Hong Cha & Bardolino Superiore \\
\hline 61 & 剑南春酒 & $\begin{array}{c}\text { Jian Nan Chun Jiu/Jian Nan } \\
\text { Chun Chiew }\end{array}$ & Barolo \\
\hline 62 & 高炉家酒(高炉酒) & Gao Lu Jia Jiu/Gao Lu Jiu & Brachettod'Acqui \\
\hline 63 & 扳倒井酒 & Ban Dao Jing Jiu & Bresaola della Valtellina \\
\hline 64 & 沙城葡萄酒 & Shacheng Pu Tao Jiu & Brunello di Montalcino \\
\hline 65 & $\begin{array}{c}\text { 茅台酒 } \\
\text { (贵州茅台酒) }\end{array}$ & $\begin{array}{c}\text { Moutai Jiu (Kweichow } \\
\text { Moutai Jiu)/Moutai Chiew } \\
\text { (Kweichow Moutai Chiew) }\end{array}$ & Chianti \\
\hline 66 & 五粮液 & Wu Liang Ye & Conegliano-Valdobbiadene-Prosecco \\
\hline
\end{tabular}




\section{Continued}

\begin{tabular}{|c|c|c|c|}
\hline 67 & 盘锦大米 & Panjin Da Mi & Dolcetto d'Alba \\
\hline 68 & 吉县苹果 & Jixian Ping Guo & Franciacorta \\
\hline 69 & $\begin{array}{c}\text { 鄂托克阿尔巴斯山 } \\
\text { 羊肉 }\end{array}$ & $\begin{array}{c}\text { EtuokeAerbasi Shan Yang } \\
\text { Rou }\end{array}$ & Gorgonzola \\
\hline 70 & 扎兰屯黑木耳 & ZhalantunHei Mu Er & Grana Padano \\
\hline 71 & 岫岩滑子蘑 & Xiuyan Hua Zi Mo & Grappa \\
\hline 72 & 东港大黄蚬 & Donggang Da Huang Xian & Montepulciano d'Abruzzo \\
\hline 73 & 东宁黑木耳 & Dongning Hei Mu Er & Mozzarella di Bufala Campana \\
\hline 74 & 南京盐水鸭 & Nanjing Yan Shui Ya & Parmigiano Reggiano \\
\hline 75 & 千岛银珍 & Qiandao Yin Zhen & Pecorino Romano \\
\hline 76 & 泰顺三杯香茶 & Taishun San Bei Xiang Cha & Prosciutto di Parma \\
\hline 77 & 金华两头乌猪 & Jinhua Liang Tou Wu Zhu & Prosciutto di San Daniele \\
\hline 78 & 罗源秀珍菇 & LuoyuanXiu Zhen Gu & Soave \\
\hline 79 & 桐江鲈鱼 & Tongjiang Lu Yu & Taleggio \\
\hline 80 & 乐安竹笋 & Le'an Zhu Sun & Toscano/a \\
\hline 81 & 莒南花生 & Junan Hua Sheng & Vino nobile di Montepulciano \\
\hline 82 & 文登苹果 & Wendeng Ping Guo & Genièvre /Jenever/Genever4 \\
\hline 83 & 安丘大葱 & Anqiu Da Cong & $\begin{array}{c}\text { Originalilietuviškadegtinè/Original } \\
\text { Lithuanian vodka }\end{array}$ \\
\hline 84 & 香花辣椒 & Xianghua La Jiao & Steirisches Kürbiskernöl \\
\hline 85 & 麻城福白菊 & Macheng Fu Bai Ju & PolskaWódka/Polish Vodka \\
\hline 86 & 潜江龙虾 & Qianjiang Long Xia & Alentejo \\
\hline 87 & 宜都宜红茶 & Yidu Yi Hong Cha & Dão \\
\hline 88 & 大埔蜜柚 & Dapu Mi You & Douro \\
\hline 89 & 桂平西山茶 & Guiping Xi Shan Cha & Pêra Rocha do Oeste (fruit) \\
\hline 90 & 百色芒果 & BaiseMang Guo & Porto, Port or Oporto \\
\hline 91 & 巫溪洋芋 & Wuxi Yang Yu & Vinho Verde \\
\hline 92 & 四川泡菜 & Sichuan Pao Cai & Cotnari \\
\hline 93 & 纳溪特早茶 & NaxiTeZao Cha & Vinohradníckaoblast'Tokaj \\
\hline 94 & 普洱咖啡 & Pu'er Ka Fei & Vipavska dolina \\
\hline 95 & 横山大明绿豆 & Hengshan Da Ming Lü Dou & $\begin{array}{l}\text { Suomalainen Vodka/Finsk } \\
\text { Vodka/Vodka of Finland }\end{array}$ \\
\hline 96 & 眉县猕猴桃 & Meixian Mi Hou Tao & Svensk Vodka/Swedish Vodka \\
\hline 97 & 天祝白牦牛 & Tianzhu Bai Mao Niu & Scotch Whisky \\
\hline 98 & 柴达木枸杞 & Chaidamu Gou Qi & Scottish farmed salmon \\
\hline 99 & 宁夏大米 & Ningxia Da Mi & West Country Farmhouse Cheddar \\
\hline 100 & 精河枸杞 & Jinghe Gou Qi & $\begin{array}{c}\text { White Stilton cheese/Blue Stilton } \\
\text { cheese }\end{array}$ \\
\hline
\end{tabular}

Source: Official website of Department of Agriculture and Rural Development of the European Commission. 